\title{
Lagged Effects of Winter Catch Crops Followed by Sweet Corn on Onion
}

\author{
Robert Rosa ${ }^{1 *}$, Dominika Słonecka', Larysa Hajko', Alena Andrejiová2 \\ 1 Siedlce University of Natural Sciences and Humanities, Faculty of Agrobioengineering and Animal Husbandry \\ B. Prusa 14, 08-110 Siedlce, Poland \\ 2 Slovak University of Agriculture in Nitra, Faculty of Horticulture and Landscape Engineering Tulipánová 7 , \\ 94976 Nitra, Slovak Republic \\ * Corresponding author's e-mail: robert.rosa@uph.edu.pl
}

\begin{abstract}
This paper deals with lagged effects of winter catch crops on the growth, yield, and quality of onion. Each autumn for two consecutive years (2009 and 2010), hairy vetch (VV), white clover (TR), winter rye (SC), Italian ryegrass (LM), and winter turnip rape (BRT) were sown as winter catch crops. In the next two springs (2010 and 2011) they were ploughed into the soil, and after them sweet corn was grown. Similarly, in the spring of 2010 and 2011 , the farmyard manure (FYM) was applied at a dose of $30 \mathrm{t} \cdot \mathrm{ha}^{-1}$ to plots with no incorporated crops, and afterwards sweet corn was planted. Finally, sweet corn was followed by the 'Sochaczewska' and 'Stuttgarter Riesen' varieties of onion, grown in 2011 and in 2012. The effect of catch crops on onion was compared with the effect of the farmyard manure and with control plants (without organic fertilizer). The highest onion yield was recorded on the plots with incorporated FYM and hairy vetch catch crop (VV). Moreover, a statistically similar marketable yield was also recorded on the plots with the incorporated catch crops of SC, LM, BRT, and TR. Incorporated catch crops affected nutrient content in onion. The most dry matter was obtained in the onion grown on plots with incorporated LM and FYM and on control. The onion grown the second year after the incorporation of SC, BRT, VV catch crops and farmyard manure was richer in protein than that grown on control. The content of sugars was the highest in the onion grown after BRT and the lowest after VV. Further research on the effectiveness of the catch crops used as green manure to grow vegetables is needed, in order to choose the best one in the following sequence: winter catch crops - sweet corn - onion.
\end{abstract}

Keywords: Allium cepa L. cepa Helm., FYM, green manure, nutritional value, organic fertilizers, yield

\section{INTRODUCTION}

According to the Food and Agriculture Organization (FAO), onion (Allium cepa $\mathrm{L}$.) is the third most cultivated vegetable in the world by production quantity, after tomato and watermelon, with a total of 94.8 million tons produced in 2016 [FAOSTAT, 2019]. In the European Union 5.9 million tons of onions were produced, about 563 thousand tonnes of which in Poland [EUROSTAT, 2020]. In the EU, Poland ranks third in the production of this vegetable.

Because of the growing demand for highquality products and an increase in the environmental awareness, the agricultural producers use more environmentally friendly production methods. One of the priorities is enriching the soil with organic matter, which restores the soil fertility and increases its buffer properties. Across Europe, the production of fertilizers of animal origin is insufficient, and, therefore, increasing attention is paid again to the green manure of plant origin [Talgre et al., 2012; Fekete and Pepó, 2018; Thavarajah et al., 2019]. Green manure should become a permanent element of improving the soil fertility in the integrated and organic farming systems. It is a factor that alleviates the negative effect of farming intensification, excessive soil compaction, and one-sided mineral fertilization [Kristensen and Thorup-Kristensen, 2004; Rogers et al., 2004; 
Choi et al. 2014]. Catch crops have a many-sided effect on the biological, physical and chemical soil properties. They reduce erosion, build up the soil organic matter, and positively influence the soil organisms [Snapp et al., 2005; Reddy, 2016]. Catch crops protect the forms of nutrients easily available for plants from leaching into the deeper layers of the soil profile and into groundwater. During the process of catch crop mineralization, the $\mathrm{N}$ biomass is gradually released and becomes available for subsequent plants [Vos and van der Putten, 2001; Reddy, 2016; Iivonen et al., 2017]. Catch crops can have a positive effect on the growth and yield of plants immediately following them, but also on those grown in the second or even third year after ploughing green manure into the soil [Hartwig and Ammon, 2002; Kołota and Adamczewska-Sowiska, 2004; Franczuk, 2006; Meena et al., 2018].

The purpose of the research was to determine the lagged effect of the winter catch crops on the size and quality of the onion bulb yield.

\section{MATERIAL AND METHODS}

The field experiment was carried out in 2009-2012 at the Agricultural Experimental Station of the Siedlce University of Natural
Sciences and Humanities, located in Central Eastern Poland $\left(52^{\circ} 03 \mathrm{~N}, 22^{\circ} 33 \mathrm{E}\right)$. The soil was classified as luvisol [IUSS, 2015], with the average organic carbon content of $0.97 \%$, the humus layer reaching the depth of $30-40 \mathrm{~cm}$, and $\mathrm{pH}_{\mathrm{KCl}}$ of 6.0. The total macronutrient content in the airdried matter amounted to $65 \mathrm{mg}$ of $\mathrm{N}_{\left(\mathrm{NO}_{3}+\right.}$ $\mathrm{NH}_{4}$ ), $67 \mathrm{mg}$ of $\mathrm{P}, 70 \mathrm{mg}$ of $\mathrm{K}, 34 \mathrm{mg}$ of $\mathrm{Mg}$, and $242 \mathrm{mg}$ of Ca per $1 \mathrm{dm}^{3}$.

The experiment was established as a splitblock design with three replicates, and it included two factors: factor I - onion cultivar, factor II - organic manure (Table 1). The catch crops were sown in the autumn of 2009 and 2010. They were incorporated each spring in 2010 and in 2011 and followed by sweet corn. At the same time, farmyard manure at a dose of $30 \mathrm{t} \cdot \mathrm{ha}^{-1}$ was applied on other plots prior to planting sweet corn. Onions were grown in 2011 and 2012, each time in the following year after the incorporation of winter catch crops and farmyard manure. The detailed dates and succession of plants are listed in Table 2, while the content of minerals in the catch crops and in the farmyard manure is presented in Table 4.

The crop preceding onion was sweet corn (Zea mays L. var. Saccharata), to which the organic treatment was applied (organic fertilizers in the form of winter crops and farm manure

Table 1. Factors of the experiment

\begin{tabular}{|c|c|}
\hline \multicolumn{2}{|c|}{ Factor I - Onion cultivars: } \\
\hline 'Sochaczewska' & $\begin{array}{l}\text { 'Sochaczewska' is a late season cultivar with a growing period of } 140 \text { to } 150 \text { days. It develops spherical } \\
\text { onions covered with dark, strong, and well-adjacent skin, with a mass of approx. } 120 \mathrm{~g} \text {. The flesh is } \\
\text { white, firm, and mild in taste. This cultivar produces high yields with a small number of thick-neck } \\
\text { onions, aligned in shape and size. It can be stored until spring. The cultivar is also intended for direct } \\
\text { market supply [http://www.pnos.pl/produkt/cebula-sochaczewska/]. }\end{array}$ \\
\hline ‘Stuttgarter Riesen’ & $\begin{array}{l}\text { 'Stuttgarter Riesen' belongs to early and mid season varieties. It develops large, round flattened onions, } \\
\text { covered with straw yellow skin. The bulbs weigh } 90-160 \mathrm{~g} \text {. The flesh is creamy with a slightly sharp } \\
\text { taste. It produces high yields, intended for direct consumption and storage [https://www.rynek-rolny.pl/ } \\
\text { artykul/cebula-stuttgarter-riesen-oryginalna-odmiana-o-szerokim-zastosowaniu.html]. }\end{array}$ \\
\hline \multicolumn{2}{|c|}{ Factor II - Organic fertilizer: } \\
\hline Control & without organic fertilizer. \\
\hline FYM & farmyard manure applied at a rate of $30 \mathrm{t} \cdot \mathrm{ha}^{-1}$, incorporated in early May in 2010 and in 2011. \\
\hline VV & $\begin{array}{l}\text { hairy vetch (Vicia villosa Roth.) winter catch crop - seeds were sown in early September at a rate of } \\
70 \mathrm{~kg} \cdot \mathrm{ha}^{-1} \text {, incorporated in early May in } 2010 \text { and in } 2011 .\end{array}$ \\
\hline TR & $\begin{array}{l}\text { white clover (Trifolium repens L.) winter catch crop - seeds were sown in early September at a rate of } \\
20 \mathrm{~kg} \cdot \mathrm{ha}^{-1} \text {, incorporated in early May in } 2010 \text { and in } 2011 .\end{array}$ \\
\hline SC & $\begin{array}{l}\text { winter rye (Secale cereale L.) winter catch crop - seeds were sown in early September at a rate of } \\
180 \mathrm{~kg} \cdot \mathrm{ha}^{-1} \text {, incorporated in early May in } 2010 \text { and in } 2011 .\end{array}$ \\
\hline LM & $\begin{array}{l}\text { Italian ryegrass (Lolium multiflorum L.) winter catch crop - seeds were sown in early September at a } \\
\text { rate of } 35 \mathrm{~kg} \cdot \mathrm{ha}^{-1} \text {, incorporated in early May in } 2010 \text { and in } 2011 .\end{array}$ \\
\hline BRT & $\begin{array}{l}\text { winter turnip rape (Brassica rapa var. typica Posp.) winter catch crop - seeds were sown in early } \\
\text { September at a rate of } 12 \mathrm{~kg} \cdot \mathrm{ha}^{-1} \text {, incorporated in early May in } 2010 \text { and in } 2011 .\end{array}$ \\
\hline
\end{tabular}


Table 2. Chronology of field operations

\begin{tabular}{|c|c|c|c|c|c|}
\hline \multirow{2}{*}{ Crops } & \multirow{2}{*}{ Field operations } & \multicolumn{4}{|c|}{ Year } \\
\hline & & 2009 & 2010 & 2011 & 2012 \\
\hline \multirow{2}{*}{$\begin{array}{l}\text { Catch crops } \\
(2009-2011)\end{array}$} & Catch crops sowing & 10.09 & 9.09 & - & - \\
\hline & $\begin{array}{l}\text { Catch crops incorporated } \\
\text { Farmyard manure incorporated }\end{array}$ & - & 11.05 & 5.05 & - \\
\hline \multirow{2}{*}{$\begin{array}{l}\text { Sweet corn } \\
(2010-2011)\end{array}$} & Sweet corn sowing & - & 24.05 & 11.05 & - \\
\hline & Sweet corn harvest & - & 23.08 & 3.09 & - \\
\hline \multirow{2}{*}{$\begin{array}{l}\text { Onion } \\
(2011-2012)\end{array}$} & Onion sowing & - & - & 14.04 & 10.04 \\
\hline & Onion harvest & - & - & 9.09 & 24.08 \\
\hline
\end{tabular}

according to the doses in Table 1) with mineral fertilizers (pre-sowing treatment: $60 \mathrm{~kg}$ of $\mathrm{N}$, $50 \mathrm{~kg}$ of $\mathrm{P}_{2} \mathrm{O}_{5}, 180 \mathrm{~kg}$ of $\mathrm{K}_{2} \mathrm{O}$ per $1 \mathrm{ha}+$ top dressing with $60 \mathrm{~kg}$ of $\mathrm{N} \cdot \mathrm{ha}^{-1}$ ).

After harvesting the cobs, the sweet corn plants were cut down and removed from the field. In autumn, the field was ploughed, and in spring, two weeks before sowing onion seeds, disc harrowing was used. Afterwards, mineral fertilizers were applied up to the optimal level for onion: $130 \mathrm{~kg}$ of N, $100 \mathrm{~kg}$ of $\mathrm{P}_{2} \mathrm{O}_{5}$, and $200 \mathrm{~kg}$ of $\mathrm{K}_{2} \mathrm{O}$ per ha.

The seeds of 'Sochaczewska' and 'Stutgarter Riesen', two cultivars of common onion, were sown directly in the ground. The description of the varieties is presented in Table 1. The seeds of each cultivar were dressed (Zaprawa Nasienna $T$ and Biosept $33 \mathrm{SL}$ ) and sown at a ratio of $6 \mathrm{~kg} \cdot \mathrm{ha}^{-1}$ on 14 and 10 April with $30 \mathrm{~cm}$ spacing. The area of a plot (unit) was $8 \mathrm{~m}^{2}(2 \mathrm{~m} \times 4 \mathrm{~m})$. The area of the whole field together with paths between the experimental combinations and replicates $(2 \mathrm{~m})$ was $880 \mathrm{~m}^{2}$. After planting, the experimental plots were sprayed with the Stomp 330 EC herbicide. Weeding in the later stages of the onion growing season was done by hand. Other treatments were performed if necessary, on the basis of an up-todate integrated onion protection program.
Onion was harvested by hand on 9 September in 2011 and on 24 August in 2012. The area of each plot to be harvested was $4.8 \mathrm{~m}^{2}$. The total and marketable yields of bulbs $\left(\mathrm{t} \cdot \mathrm{ha}^{-1}\right)$ were determined after the harvest. From each plot, a sample of bulbs was collected (about $1 \mathrm{~kg}$ ) for the chemical analysis to determine: the dry matter content by drying to the constant mass at $105^{\circ} \mathrm{C}$ [Polish Standard PN-EN-12145, 2001]; the protein and total $\mathrm{N}$ content with the Kjeldahl method, using the 6.25 factor [AOAC, 1984]; the total sugars content with the Luff-Schoorl method [EU, 2009]; L-ascorbic acid content with the Tillmans method [Polish Standard PN-A-04019, 1998]. In 2009-2011, the quantity of fresh and dry matter of catch crops and the content of accumulated macronutrients were determined. The $\mathrm{P}$ content was measured using colorimetry with the SPEKOL 221 spectrophotometer (Carl Zeiss AG, Germany) and the total $\mathrm{N}$ content with the Kjeldahl method. The content of $\mathrm{K}$ and $\mathrm{Ca}$ was determined with the FLAPHO 41 flame photometer (Carl Zeiss AG, Germany). The content of Mg was determined with the SOLAR 929 absorption spectrophotometer (ATI Unicam Ltd., UK).

The results were statistically processed with ANOVA for a split-block design. The significance of differences was determined with Tukey's test

Table 3. Weather condition in the experiment area, 2011-2012 (Zawady Meteorological Station, Poland)

\begin{tabular}{|c|c|c|c|c|c|c|c|}
\hline \multirow{2}{*}{ Years } & \multicolumn{5}{|c|}{ Month } & \multicolumn{2}{|c|}{ Mean / Sum } \\
\hline & IV & V & VI & VII & VIII & IV-VIII & I-XII \\
\hline \multicolumn{8}{|c|}{ Air temperature $\left({ }^{\circ} \mathrm{C}\right)$} \\
\hline 2011 & 10.1 & 13.5 & 18.1 & 18.3 & 18.0 & 15.6 & 8.2 \\
\hline 2012 & 8.9 & 14.6 & 16.3 & 20.7 & 18.1 & 15.7 & 7.9 \\
\hline $1951-1990$ & 7.2 & 13.2 & 16.2 & 17.6 & 16.9 & 14.2 & 7.5 \\
\hline \multicolumn{8}{|c|}{ Precipitation (mm) } \\
\hline 2011 & 31.0 & 36.1 & 39.1 & 120.2 & 18.6 & 245.0 & 317.6 \\
\hline 2012 & 29.9 & 53.4 & 76.2 & 43.0 & 51.0 & 253.5 & 389.9 \\
\hline $1951-1990$ & 29.4 & 54.3 & 69.3 & 70.6 & 59.8 & 283.4 & 514.9 \\
\hline
\end{tabular}


at the significance level of $P \leq 0.05$. All the calculations were performed with the Statistica software (version 10, Statsoft, USA).

The basic weather conditions of the experimental area in individual growing seasons are presented in Table 3. The average annual air temperatures in 2011 and 2012 were $0.7^{\circ} \mathrm{C}$ and $0.4^{\circ} \mathrm{C}$ higher than the average perennial temperature. During the onion growing period (April-August), the average air temperature throughout the research exceeded the average perennial temperature by $1.4-1.5^{\circ} \mathrm{C}$. It was extremely hot in July 2012, with the average air temperature of $20.7^{\circ} \mathrm{C}$. Combined with a small amount of precipitation, such conditions stopped the growth and formation of onions, and accelerated drying of chives. The amount of precipitation during the years of research was significantly lower than the average perennial value. The annual rainfall was $197.3 \mathrm{~mm}$ lower in 2011 than the perennial average, and $125 \mathrm{~mm}$ lower in 2012. During the onion growing season, there was $245 \mathrm{~mm}$ of rain in 2011, with half of it (120.2 mm) in July. In 2012, good moisture conditions occurred in spring, which promoted seed germination and the formation of chives. However, only $43 \mathrm{~mm}$ of rain fell in July, which, combined with high air temperatures, shortened the growing period and lowered the onion yield.

\section{RESULTS AND DISCUSSION}

The quantity of fresh and dry matter and the macronutrient content in the incorporated catch crops varied across the years of research (Table 4). On average, between 2010 and 2011 the highest yields of fresh matter $\left(35.2 \mathrm{t} \cdot \mathrm{ha}^{-1}\right)$ were recorded for winter rye, and the lowest $\left(10.9 \mathrm{t} \cdot \mathrm{ha}^{-1}\right)$ for Italian ryegrass. OReilly et al. [2011] and Dolijanowic et al. [2012] reported that the biomass produced by the catch crops of rye and hairy vetch amounted even up to $30 \mathrm{t} \cdot \mathrm{ha}^{-1} \mathrm{FYM}$. In the present research, both winter rye and winter turnip rape produced a quantity of biomass exceeding $30 \mathrm{t} \cdot \mathrm{ha}^{-1}$, while the yield of hairy vetch as a catch crop was $17.9 \mathrm{t} \cdot \mathrm{ha}^{-1}$. The highest amount of dry matter was produced by winter rye $\left(6.7 \mathrm{t} \cdot \mathrm{ha}^{-1}\right)$ and the lowest by white clover and Italian ryegrass $\left(2.2 \mathrm{t} \cdot \mathrm{ha}^{-1}\right)$.

The largest amounts of $\mathrm{N}$ were introduced into the soil together with winter rye, hairy vetch and winter turnip rape $\left(109.5-118.3 \mathrm{~kg} \cdot \mathrm{ha}^{-1}\right)$. These were the quantities corresponding to the quantity of $\mathrm{N}$ ploughed into the soil together with the farmyard manure at a dose of $30 \mathrm{t} \cdot \mathrm{ha}^{-1}$. White clover enriched the soil with $68.5 \mathrm{~kg} \mathrm{~N} \cdot \mathrm{ha}^{-1}$ and Italian ryegrass with $37.5 \mathrm{~kg} \mathrm{~N} \cdot \mathrm{ha}^{-1}$. The quantity of $\mathrm{P}$ in winter turnip rape was higher than in the farmyard manure, but in winter rye it was similar.

Table 4. The quantity of fresh and dry matter and the amount of macroelements incorporated with farmyard manure and catch crops

\begin{tabular}{|c|c|c|c|c|c|c|c|c|}
\hline \multirow{2}{*}{$\begin{array}{l}\text { Kind of organic } \\
\text { manure / catch crops }\end{array}$} & \multirow{2}{*}{$\begin{array}{c}\text { Year of } \\
\text { incorporated }\end{array}$} & \multirow{2}{*}{$\begin{array}{c}\text { Fresh matter, } \\
\mathrm{t} \cdot \mathrm{ha}^{-1}\end{array}$} & \multirow{2}{*}{$\begin{array}{l}\text { Dry matter, } \\
{\mathrm{t} \cdot \mathrm{ha}^{-1}}^{-}\end{array}$} & $\mathrm{N}$ & $\mathrm{P}$ & $\mathrm{K}$ & $\mathrm{Ca}$ & $\mathrm{Mg}$ \\
\hline & & & & \multicolumn{5}{|c|}{ Accumulation, $\mathrm{kg} \cdot \mathrm{ha}^{-1}$} \\
\hline \multirow{3}{*}{$\begin{array}{l}\text { Farmyard manure } \\
\text { (FYM) }\end{array}$} & 2010 & 30.0 & 7.6 & 106.4 & 49.7 & 140.0 & 70.1 & 39.1 \\
\hline & 2011 & 30.0 & 8.1 & 120.7 & 53.1 & 133.2 & 64.1 & 45.4 \\
\hline & Mean & 30.0 & 7.9 & 113.6 & 51.4 & 136.6 & 67.1 & 42.3 \\
\hline \multirow{3}{*}{$\begin{array}{l}\text { Hairy vetch } \\
\text { (VV) }\end{array}$} & 2010 & 15.7 & 2.6 & 92.9 & 8.9 & 36.7 & 23.8 & 6.1 \\
\hline & 2011 & 20.0 & 3.4 & 127.7 & 14.3 & 46.0 & 29.0 & 6.8 \\
\hline & Mean & 17.9 & 3.0 & 110.3 & 11.6 & 41.4 & 26.4 & 6.5 \\
\hline \multirow{3}{*}{$\begin{array}{l}\text { White clover } \\
\text { (TR) }\end{array}$} & 2010 & 12.4 & 2.4 & 84.8 & 10.4 & 62.7 & 25.1 & 7.4 \\
\hline & 2011 & 10.6 & 1.9 & 52.1 & 8.6 & 47.2 & 20.0 & 5.3 \\
\hline & Mean & 11.5 & 2.2 & 68.5 & 9.5 & 55.0 & 22.6 & 6.4 \\
\hline \multirow{3}{*}{$\begin{array}{l}\text { Winter rye } \\
\quad(\mathrm{SC})\end{array}$} & 2010 & 35.1 & 6.9 & 120.7 & 54.4 & 150.7 & 55.2 & 25.2 \\
\hline & 2011 & 35.3 & 6.4 & 115.9 & 50.1 & 128.7 & 49.9 & 23.7 \\
\hline & Mean & 35.2 & 6.7 & 118.3 & 52.3 & 139.7 & 52.6 & 24.5 \\
\hline \multirow{3}{*}{$\begin{array}{l}\text { Italian ryegrass } \\
\text { (LM) }\end{array}$} & 2010 & 9.5 & 1.9 & 31.2 & 10.9 & 99.4 & 11.7 & 7.2 \\
\hline & 2011 & 12.4 & 2.5 & 43.8 & 13.5 & 128.7 & 18.4 & 7.9 \\
\hline & Mean & 11.0 & 2.2 & 37.5 & 12.2 & 114.1 & 15.1 & 7.6 \\
\hline \multirow{3}{*}{$\begin{array}{l}\text { Winter turnip rape } \\
\text { (BRT) }\end{array}$} & 2010 & 30.8 & 5.7 & 119.2 & 100.9 & 230.4 & 105.5 & 11.1 \\
\hline & 2011 & 30.4 & 4.5 & 99.7 & 71.5 & 172.7 & 76.7 & 9.8 \\
\hline & Mean & 30.6 & 5.1 & 109.5 & 86.2 & 201.6 & 91.1 & 10.5 \\
\hline
\end{tabular}


The non-leguminous catch crops and FYM contained significantly more $\mathrm{K}$ than the leguminous catch crops. Winter rape turnip enriched the soil with much more $\mathrm{Ca}$ and winter rye with more $\mathrm{Mg}$ than the other catch crops. The total amount of macronutrients ( $\mathrm{N}, \mathrm{P}, \mathrm{K}, \mathrm{Ca}, \mathrm{Mg})$ accumulated by those crops accounted for between 39.4\% (white clover) and $121.4 \%$ (winter turnip rape) of the amounts introduced into the soil with the $30 \mathrm{t} \cdot \mathrm{ha}^{-1} \mathrm{FYM}$.

Thorup-Kristensen [2001] and Kramberger et al. [2009] reported that rye and turnip rape are two of the most effective catch crop plants recovering nutrients from deeper soil strata. The quantity of macronutrients accumulated by catch crops depends on a number of factors, including the catch crop species, soil type, climatic conditions, and timing of agricultural operations. $\mathrm{N}$ is the element which exerts the greatest effect on the yield.
The amounts of $\mathrm{N}$ in hairy vetch may range from 52 to $227 \mathrm{~kg} \cdot \mathrm{ha}^{-1}$ [Caporali et al., 2004; Franczuk, 2006; Salmerón et al., 2011]. White clover leaves soil in good condition, fixing from 100 to $240 \mathrm{~N} \cdot \mathrm{ha}^{-1}$ [Kramberger et al., 2014]. In turn, rye may enrich the soil with $40-143 \mathrm{~kg} \mathrm{~N} \cdot \mathrm{ha}^{-1}$ [Thorup-Kristensen, 2001; Franczuk, 2006].

In the present experiment, the weather conditions in the successive years had a significant influence on the total and marketable yields of onion (Table 5). The yield in 2011 was significantly higher than in 2012. The difference between those two growing seasons was $17 \%$ in the total yield and $23 \%$ in the marketable yield. The average total and marketable yields of 'Sochaczewska' onions were 36.1 and $31.3 \mathrm{t} \cdot \mathrm{ha}^{-1}$, with 27.9 and $24.2 \mathrm{t} \cdot \mathrm{ha}^{-1}$ of 'Stuttgarter Riesen' onion. Those statistically significant differences were due to the genetic conditions.

Table 5. Yielding of onion $\left(\mathrm{t} \bullet \mathrm{ha}^{-1}\right)$

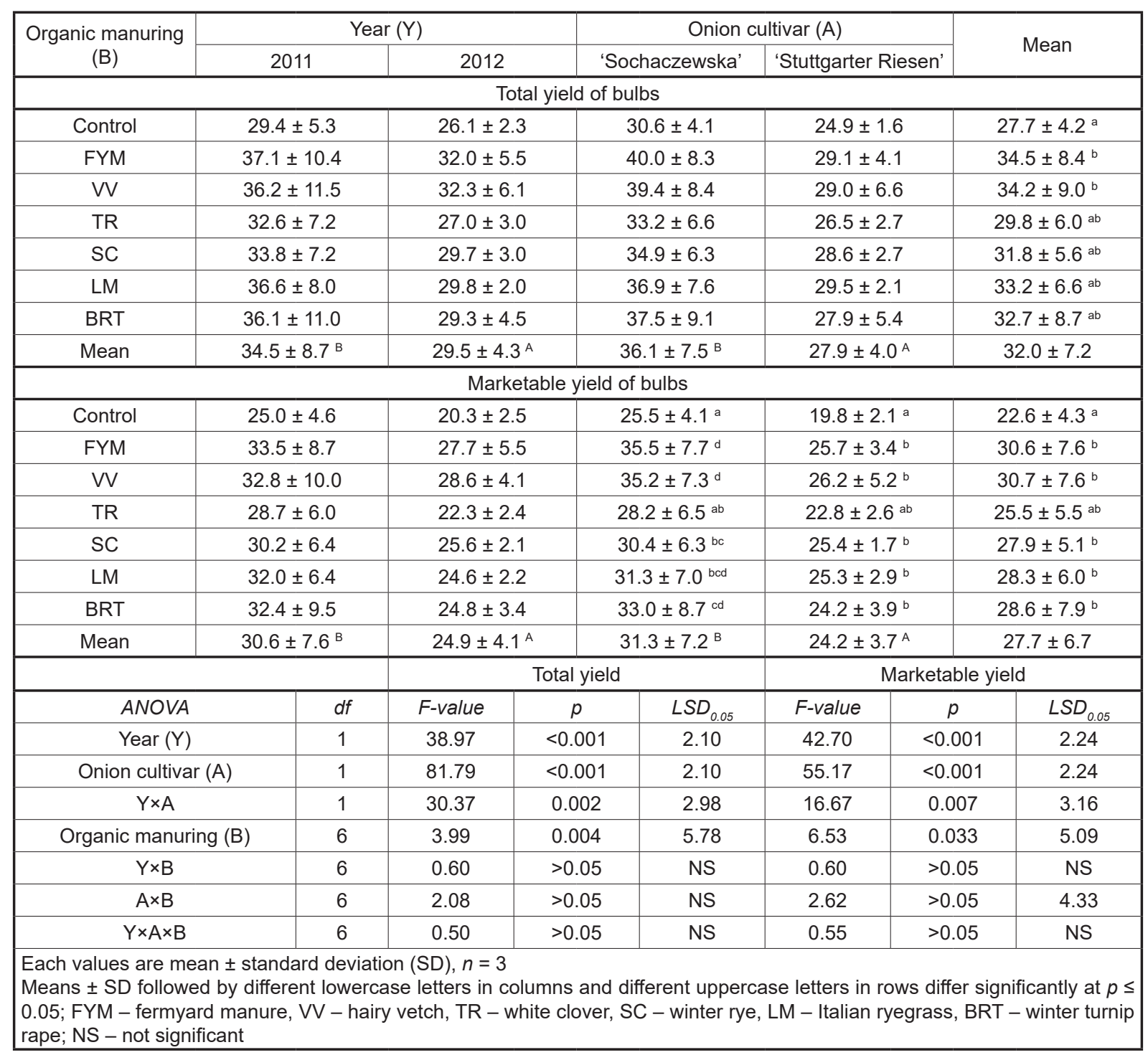


The statistical analysis of the results also showed a significant effect of organic fertilizers applied to sweet corn preceding onion on the yield of the latter (Table 5). The largest onion yield, average for both varieties and growing seasons, was on the plots with incorporated manure $\left(34.5 \mathrm{t} \cdot \mathrm{ha}^{-1}\right)$ and hairy vetch $\left(34.2 \mathrm{t} \cdot \mathrm{ha}^{-1}\right)$. This yield was significantly larger than from the control plot, without organic fertilizers. Winter catch crops, incorporated before sugar corn, had an effect on the onion yield similar to that of manure applied at a dose of $30 \mathrm{t} \cdot \mathrm{ha}^{-1}$. The onions grown on the plots with manure, VV, SC, LM and BRT, incorporated the previous year, produced a significantly higher marketable yield than those grown in control, without organic fertilizers. The largest increase in the marketable yield (more than 35\%) compared to control was obtained after ploughing FYM and VV into the soil (Figure 1). Compared to the plot with FYM, a 5-16.7\% reduction in the marketable yield of onion (Figure 1) grown after TR, SC, LM and BRT was observed. However, these differences were within the statistical error.

Willumsen and Thorup-Kristensen [2001] pointed to a high pre-crop effect of hairy vetch. They demonstrated that onion and white cabbage produced the highest yields when they were grown after hairy vetch or after a mixture of hairy vetch and winter rye. Stavridou et al. [2012] also recorded the beneficial effects of hairy vetch and Italian ryegrass on the yield of onion. However, despite higher yields than in control, without catch crops, the differences were not statistically proven. Many researchers point out that the use of green manure in crop rotation is aimed not only at increasing the yield of plants following them or at reducing the amounts of mineral fertilisers. Catch crops should be planted due to the ecological reasons, such as reduction of weed infestation and herbicide use, limiting soil erosion, recovery of nutrients from deeper soil strata and protection against them being leached out into groundwater, increase in the amount of organic matter and of micro and mesofauna in the soil [Snapp et al., 2005; Rosa, 2015; Reddy, 2016].

According to Lee and Kadar [2000], the quality of vegetables depends, among others, on the content of vitamins, minerals, and proteins. These characteristics are genetically determined, but can be modified by the factors affecting plants during their growth, i.e. weather conditions, agronomical practice, fertilisers, or using intercrops to cover the soil [Lee and Kadar, 2000; Kołota and Adamczewska-Sowiska, 2004; Olfati et al., 2008].

The content of selected nutrients in onion was also examined in the experiment. The 'Stuttgarter Riesen' cultivar contained significantly more dry matter, protein, total sugars and ascorbic acid than 'Sochaczewska' (Tables 6-7). These differences were statistically significant. The climatic conditions during the years of research differentiated only the protein content. Onion contained significantly more protein in 2012, than the year before.

The average dry matter (DM) content of the 'Sochaczewska' onion was $11.36 \%$, with $12.52 \%$ in 'Stuttgarter Riesen' (Table 6). This content was differentiated by various organic fertilizers incorporated before sweet corn. The 'Sochaczewska' cultivar contained the highest amounts of dry matter on the plots with incorporated FYM, and significantly less on the plots with VV. It was also found that the 'Stuttgarter Riesen' onion grown in
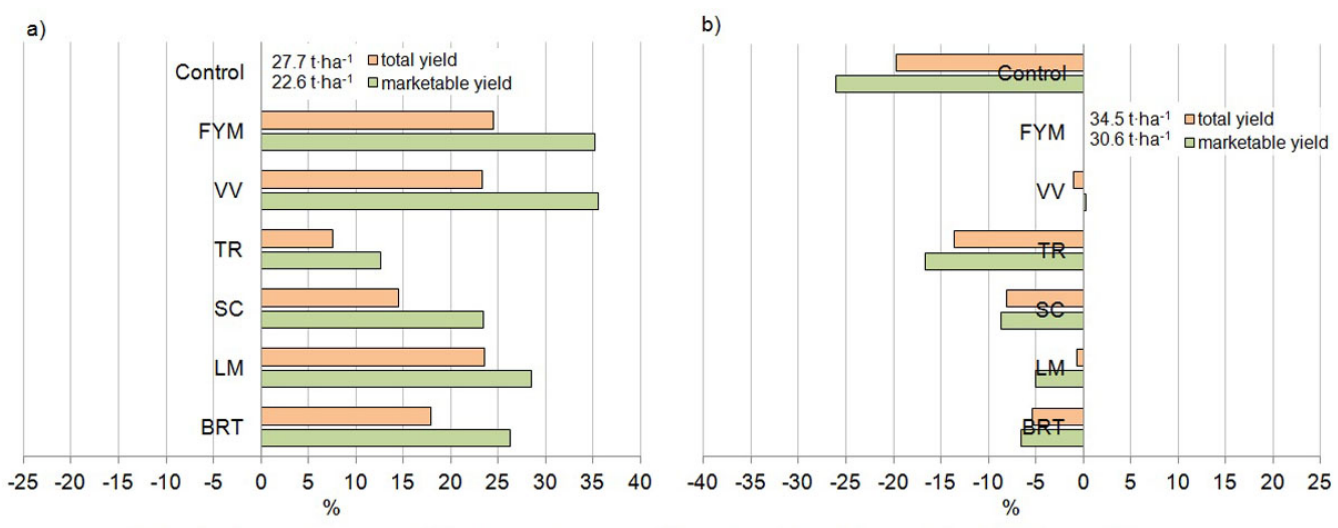

Control-without organic manure, FYM- farmyard manure, VV-hairy vetch catch crop, TR - white clover catch crop, $\mathrm{SC}$ - winter rye catch crop, LM - italian ryegrass catch crop, BRT - winter turnip rape catch crop

Figure 1. The procentage increase/decrease the yields of onion bulbs in comparison to control without the organic manure NOM (a) and combination with FYM

(b) depending on the kind of winter catch crops (mean for years) 
the second year after LM, TR, and FYM and on the control contained significantly more dry matter than after SC and BRT.

The largest protein content (1.25\% FM), average for both varieties, was found in the onion grown in the second year after the winter rye (SC) incorporation. The onion grown after the VV and LM catch crops, as well as after FYM, contained statistically similar amounts of dry matter (Table 6). In the onion of the 'Sochaczewska' cultivar the most protein $(1.22-1.23 \% \mathrm{FM})$ was found on the plots with incorporated manure, $\mathrm{VV}$, and BRT. It was significantly more than in the onion from control and from the plots with incorporated LM. In the onion of the 'Stuttgarter Riesen' cultivar, the highest statistically significant amount of protein was found when it grew after incorporated SC. The highest amounts of total $\mathrm{N}$ (Table 4) were recorded in the onion on the plots with farmyard manure (FYM), winter rye (SC), hairy vetch (VV), and winter turnip rape (BRT). After the mineralization of organic matter, taking place in the first and second years after FYM and catch crop incorporation, $\mathrm{N}$ became available to onion. The plants used it for tissue building and protein synthesis. According to Worthington [2001] and Talgre et al. [2012], an increase in the available $\mathrm{N}$ content stimulates the protein production, which may explain the increased protein amounts in the plants following winter vetch, winter rye and winter turnip rape. The increased content of protein was recorded earlier by Jabłońska-Ceglarek and Rosa [2003], who used the spring-incorporated green manures.

As an average for the years of research and varieties, the highest total sugars content $\left(7.14 \mathrm{~g} \cdot 100^{-1} \mathrm{FM}\right)$ was found in the onion grown after winter turnip rape (BRT), which, like the

Table 6. Dry matter content and protein in onion

\begin{tabular}{|c|c|c|c|c|c|c|c|c|c|c|}
\hline \multirow{2}{*}{$\begin{array}{l}\text { Organic manuring } \\
\text { (B) }\end{array}$} & \multicolumn{4}{|c|}{ Year $(\mathrm{Y})$} & \multicolumn{4}{|c|}{ Onion cultivar (A) } & \multirow{2}{*}{\multicolumn{2}{|c|}{ Mean }} \\
\hline & \multicolumn{2}{|c|}{2011} & \multicolumn{2}{|c|}{2012} & \multicolumn{2}{|c|}{ 'Sochaczewska' } & \multicolumn{2}{|c|}{ 'Stuttgarter Riesen' } & & \\
\hline \multicolumn{11}{|c|}{ Dry matter, $\%$} \\
\hline Control & \multicolumn{2}{|c|}{$12.11 \pm 0.98^{b}$} & \multicolumn{2}{|c|}{$12.18 \pm 0.62 \mathrm{ab}$} & \multicolumn{2}{|c|}{$11.50 \pm 0.45^{\mathrm{ab}}$} & \multicolumn{2}{|c|}{$12.80 \pm 0.35^{\mathrm{cd}}$} & \multicolumn{2}{|c|}{$12.15 \pm 0.78^{b c}$} \\
\hline FYM & \multicolumn{2}{|c|}{$11.75 \pm 0.85 \mathrm{ab}$} & \multicolumn{2}{|c|}{$12.30 \pm 0.56^{b}$} & \multicolumn{2}{|c|}{$11.54 \pm 0.76^{b}$} & \multicolumn{2}{|c|}{$12.52 \pm 0.26^{c}$} & \multicolumn{2}{|c|}{$12.03 \pm 0.75^{b c}$} \\
\hline VV & \multicolumn{2}{|c|}{$11.76 \pm 1.08$ ab } & \multicolumn{2}{|c|}{$11.88 \pm 0.61$ ab } & \multicolumn{2}{|c|}{$11.14 \pm 0.48^{a}$} & \multicolumn{2}{|c|}{$12.50 \pm 0.44 \mathrm{bc}$} & \multicolumn{2}{|c|}{$11.82 \pm 0.84 \mathrm{abc}$} \\
\hline TR & \multicolumn{2}{|c|}{$11.82 \pm 0.96 \mathrm{ab}$} & \multicolumn{2}{|c|}{$12.11 \pm 0.46 \mathrm{ab}$} & \multicolumn{2}{|c|}{$11.37 \pm 0.53 \mathrm{ab}$} & \multicolumn{2}{|c|}{$12.57 \pm 0.20^{c}$} & \multicolumn{2}{|c|}{$11.97 \pm 0.74 \mathrm{abc}$} \\
\hline SC & 11.5 & $.75^{a}$ & $11.78 \pm$ & & & $17 \pm 0.48$ ab & $12.10 \pm$ & & & $64 \pm 0.61^{a}$ \\
\hline LM & 12.0 & $.38^{b}$ & $12.31 \pm$ & & & $32 \pm 0.68 \mathrm{ab}$ & $13.04 \pm$ & & & $18 \pm 1.04^{c}$ \\
\hline BRT & 11.8 & $46^{\mathrm{ab}}$ & $11.73 \pm$ & & & $44 \pm 0.17$ ab & $12.13 \pm$ & & & $88 \pm 0.43$ ab \\
\hline Mean & 11. & 0.91 & $12.04 \pm$ & & & $35 \pm 0.52^{A}$ & $12.52 \pm$ & & & $.94 \pm 0.76$ \\
\hline & & & Prote & 10 & fre & ch matter & & & & \\
\hline Control & & 0.04 & $1.18 \pm$ & & & $3 \pm 0.06$ ab & $1.17 \pm 0$ & & & $5 \pm 0.06^{a}$ \\
\hline FYM & & 0.08 & $1.26 \pm$ & & & $3 \pm 0.04^{c}$ & $1.25 \pm$ & & & $4 \pm 0.06$ bc \\
\hline VV & & 0.09 & $1.27 \pm$ & & & $24 \pm 0.08^{c}$ & $1.23 \pm 0$ & & & $4 \pm 0.07 \mathrm{bc}$ \\
\hline TR & & .07 & $1.22 \pm$ & & & $8 \pm 0.06 \mathrm{abc}$ & $1.16 \pm$ & & & $7 \pm 0.08$ ab \\
\hline SC & & .13 & $1.32 \pm$ & & & $9 \pm 0.11$ bc & $1.32 \pm$ & & & $25 \pm 0.12^{c}$ \\
\hline LM & & .07 & $1.22 \pm$ & & & $2 \pm 0.08^{a}$ & $1.22 \pm 0$ & & & $7 \pm 0.09$ ab \\
\hline BRT & & .03 & $1.29 \pm$ & & & $2 \pm 0.07^{c}$ & $1.24 \pm$ & & & $3 \pm 0.07$ bc \\
\hline Mean & 1.1 & $.09^{\mathrm{A}}$ & $1.25 \pm 0$ & & & $19 \pm 0.08^{A}$ & $1.23 \pm 0$ & & & $21 \pm 0.09$ \\
\hline & & & & Dry & & & & Prot & & \\
\hline ANOVA & & $d f$ & $F$-value & & & $L S D_{0.05}$ & $F$-value & $p$ & & $L S D_{0.05}$ \\
\hline Year $(\mathrm{Y})$ & & 1 & 5.65 & & & NS & 76.85 & $<0$. & & 0.026 \\
\hline Onion cultiva & & 1 & 92.77 & & & 0.279 & 12.81 & 0.0 & & 0.026 \\
\hline $\mathrm{Y} \times \mathrm{A}$ & & 1 & 10.19 & & & 0.395 & 2.88 & $>0$ & & NS \\
\hline Organic manuri & (B) & 6 & 4.69 & & & 0.353 & 7.24 & $<0$. & & 0.074 \\
\hline$Y \times B$ & & 6 & 3.13 & & & 0.499 & 1.50 & $>0$. & & NS \\
\hline$A \times B$ & & 6 & 4.25 & & & 0.384 & 4.14 & 0.0 & & 0.073 \\
\hline$Y \times A \times B$ & & 6 & 1.82 & & & NS & 2.08 & $>0$. & & NS \\
\hline
\end{tabular}


other catch crops, was grown after sugar corn. This content was significantly higher than in the onion grown on the plots with incorporated manure (FYM), VV, and SC (Table 7). It was also found that the onion grown after LM was statistically significantly richer in the sugars than that grown after VV. In the case of the 'Sochaczewska' onion, the highest amounts of total sugars $\left(7.15 \mathrm{~g} \cdot 100 \mathrm{~g}^{-1} \mathrm{FM}\right)$ were found when it was grown after RG and, in the case of 'Stuttgarter Riesen' after LM (7.36 g· $\left.100 \mathrm{~g}^{-1} \mathrm{FM}\right)$.

The average content of $\mathrm{L}$-ascorbic acid in onion was $5.06 \mathrm{mg} \cdot 100 \mathrm{~g}^{-1} \mathrm{FM}$ (Table 7). Its largest content was noted in the onion grown after $\mathrm{VV}$ $\left(5.20 \mathrm{mg} \cdot 100 \mathrm{~g}^{-1} \mathrm{FM}\right)$ and also in control, without organic fertilizers $\left(5.17 \mathrm{mg} \cdot 100 \mathrm{~g}^{-1} \mathrm{FM}\right)$. Significantly less L-ascorbic acid was found in the onion from the FYM and BRT plots.

\section{CONCLUSION}

1. The effect of winter catch crops ploughed into the soil, like Vicia villosa Roth., Trifolium repens L., Secale cereale L., Lolium multiflorum L., and Brassica rapa var. Typical, on the yield of onion bulbs was statistically similar to that of manure applied at a dose of $30 \mathrm{t} \cdot \mathrm{ha}^{-1}$.

2. Among the above-mentioned catch crops, hairy vetch affected the yield of subsequent crops the most.

3. Organic fertilizers applied to the crops preceding onion affected its content of dry matter, protein, sugars, and L-ascorbic acid.

4. The most dry matter was recorded in the onion grown after Italian ryegrass and FYM, as well as in the control plot. Onion grown after the incorporation of winter rye, winter turnip rape,

Table 7. Total sugars content and L-ascorbic acid in onion

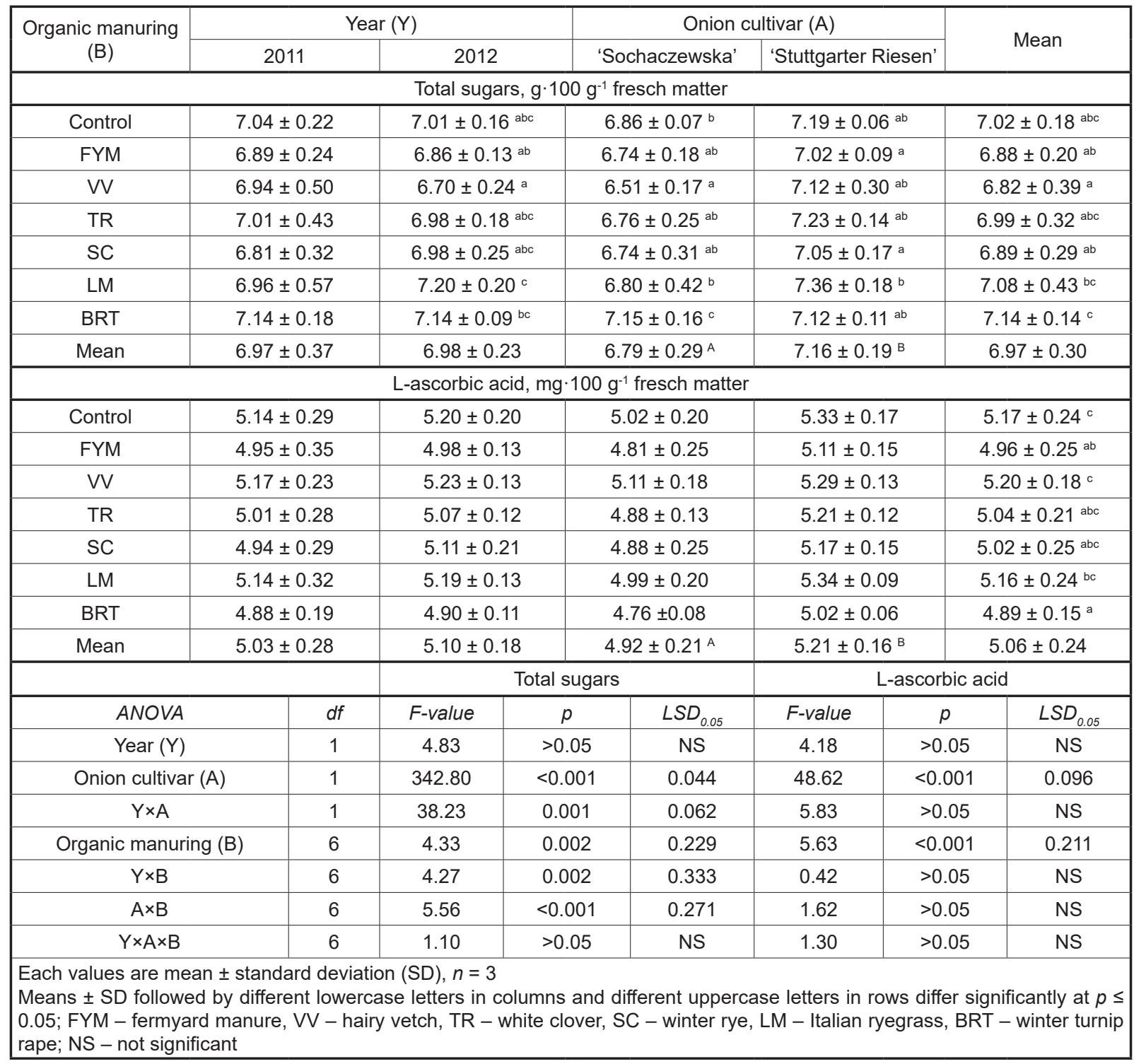


hairy vetch catch crops, and farmyard manure was richer in protein than the control plants. The highest amounts of sugars were found in the onion grown after winter turnip rape incorporated as a catch crop and the lowest after hairy vetch. However, in the onion grown after hairy vetch the largest content of L-ascorbic acid was reported.

5. It was found that in horticulture, the winter catch crops, especially hairy vetch, winter rye, Italian ryegrass, and winter turnip rape, can be an alternative to manure, an organic fertilizer increasingly more difficult to obtain. The beneficial effect of those cropson the yield of succesive crops, similar to that of manure, was also evident in the second year. They all can be successfully used in the following sequence: winter catch crops - sweet corn - onion.

\section{Acknowledgements}

The research was carried out under the research project No. 226/06/S, financed from a science grant by the Ministry of Science and Higher Education.

\section{REFERENCES}

1. AOAC 1984. Association of Official Analytical Chemists. Official methods of analysis. 14th ed. Assn. Official Analytical Chemists, Arlington, Va. sec. 14.067.

2. Caporali F., Campiglia E., Mancinelli R., Paolini R. 2004. Maize performances as influenced by winter cover crop green manure. Italian Journal of Agronomy, 8(1). 37-45.

3. Choi B., Lim J.E., Sung J.K., Jeon W.T., Lee S.S., Oh S.-E., Yang J.E., Ok Y.S. 2014. Effect of Rapeseed green manure amendment on soil properties and rice productivity. Communications in Soil Science and Plant Analysis, 45(6), 751-764. doi:10.1 080/00103624.2013.858728

4. Dolijanovic Z., Momirovic N., Mihajlovic V., Simic M., Oljaca S., Kovacevic D., Kaitovic Z. 2012. Cover crops effects on the yield of sweet corn. Third International Scientific Sympozjum "Agrosym Jahorina 2012", 104-110.

5. EU 2009. Commission Regulation NO 152/2009. Official Journal of the European Union L54, 1-130.

6. EUROSTAT 2019. Agricultural production-crops, https:/ec.europa.eu/eurostat/statistics-explained/ index.php?title=Agricultural_production_crops\#Vegetables [access: 6.03.2020].
7. FAOSTAT 2019: Food and Agriculture Organization of the United Nations. (Rome), FAO, 2019.

8. Fekete Á., Pepó P. 2018. The role of green manure crops in Hungarian plant production. Acta Agraria Debreceniensis, 74, 49-53. doi:10.34101/ actaagrar/74/1663

9. Franczuk J. 2006. Efekty stosowania nawozów zielonych w postaci międzyplonów ozimych oraz słomy żytniej w uprawie warzyw. (The effects of the use of green manure in the form of winter catch crops and rye straw in the cultivation of vegetables). Wydawnictwo Akademii Podlaskiej w Siedlcach, Rozprawa Nauk., 84, 122 p. (in Polish)

10. Hartwig N., Ammon H. 2002. Cover crops and living mulches. Weed Science, 50(6), 688-699. doi:1 0.1614/0043-1745(2002)050[0688:aiacca]2.0.co;2

11. http://www.pnos.pl/produkt/cebula-sochaczewska/ [access: 2/03/2020]

12. https://www.rynek-rolny.pl/artykul/cebula-stuttgarter-riesen-oryginalna-odmiana-o-szerokim-zastosowaniu.html [access: 2/03/2020]

13. Iivonen S., Kivijärvi P., Suojala-Ahlfors T. 2017. Characteristics of various catch crops in the organic vegetable production in northern climate conditions - Results from and on-farm study. Reports 165. University of Helsinki, Ruralia Institute. http://hdl. handle.net/10138/229443 [access: 15/03/2020]

14. IUSS Working Group WRB 2015. World Reference Base for Soil Resources 2014 (update 2015). International Soil Classification System for Naming Soils and Creating Legends for Soil Maps. World Soil Resources Reports No. 106. Rome, FAO.

15. Jabłońska-Ceglarek R., Rosa R. 2003. Influence of green manures on the quantity and quality of the yield of red beet. Acta Scientiarum Polonorum, Hortorum Cultus, 2(1), 21-30. (in Polish with English summary)

16. Kołota E., Adamczewska-Sowiska K. 2004. The effects of living mulches on yield, overwintering and biological value of leek. Acta Horticulture, 638, 209-214.

17. Kramberger B., Gselman A., Janzekovic M., Kaligaric M., Bracko B. 2009. Effects of cover crops on soil mineral $\mathrm{N}$ and on the yield and $\mathrm{N}$ content of maize. European Journal of Agronomy, 31(2), 103-109. doi:10.1016/j.eja.2009.05.006

18. Kramberger B., Gselman A., Kristl J., Lešnik M., Šuštar V., Muršec M., Podvršnik M. 2014. Winter cover crop: the effects of grass-clover mixture proportion and biomass management on maize and the apparent residual $\mathrm{N}$ in the soil. European Journal of Agronomy, 55, 63-71. doi:10.1016/j. eja.2014.01.001

19. Kristensen H., Thorup-Kristensen K. 2004. Root growth and nitrate uptake of three different catch 
crops in deep soil layers. Soil Science Society of America Journal, 68(2), 529-537. doi:10.2136/ sssaj2004.5290

20. Lee S.K., Kader A.A. 2000. Preharvest and postharvest factors influencing vitamin $\mathrm{C}$ content of horticultural crops. Postharvest Biology and Technology, 20(3), 207-220. doi:10.1016/ s0925-5214(00)00133-2

21. Meena B.L., Fagodiya R.K., Prajapat K., Dotaniya M.L., Kaledhonkar M.J., Sharma P.C., Meena R.S., Mitran T., Kumar S. 2018. Legume green manuring: an option for soil sustainability. (in) Meena R.S. et al. (eds.). Legumes for Soil Health and Sustainable Management. Springer Singapore, 387-408. doi:1 0.1007/978-981-13-0253-4_12

22. O’Reilly K.A., Robinson D.E., Vyn R.J., Van Eerd L.L. 2011. Weed populations, sweet corn yield, and economics following fall cover crops. Weed Technology, 25(3), 374-384. doi:10.1614/ wt-d-10-00051.1

23. Olfati J.A., Peyvast Gh., Nosrati-Rad Z. 2008. Organic mulching on carrot yield and quality. International Journal of Vegetable Science, 14(4), 362-368. doi:10.1080/19315260802303404

24. Polish Standard PN-A-04019. 1998. Polish Standard. Food products - Determination of vitamin C content. Polish Committee for Standardization, Warsaw, Poland. (in Polish)

25. Polish Standard PN-EN-12145. 2001. Fruit and vegetable juices - Determination of total dry matter - Gravimetric method with loss of mass on drying. Polish Committee for Standardization, Warsaw, Poland. (in Polish)

26. Reddy P.P. 2016. Cover/Green Manure Crops. Sustainable Intensification of Crop Production, 55-67. doi:10.1007/978-981-10-2702-4_4

27. Rogers G.S., Little S.A., Silcock S.J., Williams L.F. 2004. No-till vegetable production using organic mulches. Acta Horticulturae, 638, 215-223. doi:10.17660/actahortic.2004.638.28

28. Rosa R. 2015. The effect of winter catch crops on weed infestation in sweet corn depending on the weed control methods. Journal of Ecological Engineering, 16(2), 125-135. doi:10.12911/22998993/1867

29. Salmerón M., Isla R., Cavero J. 2011. Effect of winter cover crop species and planting methods on maize yield and $\mathrm{N}$ availability under irrigated Mediterranean conditions. Field Crops Research, 123(2), 89-99. doi:10.1016/j.fcr.2011.05.006

30. Snapp S.S., Swinton S.M., Labarta R., Mutch D., Black J.R., Leep R., Nyiraneza J., O’Neil K. 2005. Evaluating cover crops for benefits, costs and performance within cropping system niches. Agronomy Journal, 97, 322-332. doi:10.2134/agronj2005.0322

31. Stavridou E., Young S.D., Thorup-Kristensen K. 2012. The effect of catch crop species on selenium availability for succeeding crops. Plant and Soil, 351, 149-160. doi:10.1007/s11104-011-0940-6

32. Talgre L., Lauringson E., Roostalu H., Astover A., Makke A. 2012. Green manure as a nutrient source for succeeding crops. Plant, Soil and Environment, 58(6), 275-281. doi:10.17221/22/2012-pse

33. Thavarajah D., Siva N., Johnson N., McGee R., Thavarajah P. 2019. Effect of cover crops on the yield and nutrient concentration of organic kale (Brassica oleracea L. var. acephala). Scientific Reports, 9(1), 10374. doi:10.1038/s41598-019-46847-9

34. Thorup-Kristensen K. 2001. Are differences in root growth of $\mathrm{N}$ catch crops important for their ability to reduce soil nitrate-N content, and how can this be measured? Plant and Soil, 230, 185-195.

35. Vos J., van der Putten P.E.L. 2001. Field observations on $\mathrm{N}$ catch crops. III. Transfer of $\mathrm{N}$ to the succeeding main crop. Plant and Soil, 236, 263-273.

36. Willumsen J., Thorup-Kristensen K. 2001. Effects of Green Manure Crops on Soil Mineral Nitrogen Available for Organic Production of Onion and White Cabbage in Two Contrasting Years. Biological Agriculture and Horticulture, 18(4), 365-384, doi:10.1080/01448765.2001.9754898

37. Worthington V. 2001. Nutritional quality of organic versus conventional fruits, vegetables and grains. The Journal ofAlternative and Complementary Medicine, 7(2), 161-173. doi:10.1089/107555301750164244 